\title{
LESSONS FROM LARGE-SCALE CONSERVATION NETWORKS IN AUSTRALIA
}

\author{
James Fitzsimons ${ }^{1,2} *$, lan Pulsford ${ }^{3}$ and Geoff Wescott ${ }^{2}$ \\ * Corresponding author: jfitzsimons@tnc.org \\ ${ }^{1}$ The Nature Conservancy, Suite 2-01, 60 Leicester Street, Carlton VIC 3053, Australia \\ ${ }^{2}$ School of Life and Environmental Sciences, Deakin University, 221 Burwood Highway, Burwood \\ VIC 3125, Australia \\ ${ }^{3} 204$ Duffy Street, Ainslie ACT 2602, Australia
}

\begin{abstract}
Australia has seen a rapid growth in the establishment of networks of lands managed for connectivity conservation across tenures, at landscape and sub-continental scales. Such networks go under a variety of names, including biosphere reserves, biolinks, wildlife corridors and conservation management networks. Their establishment has varied from state government-led initiatives to those initiated by non-government organizations and interested landholders. We surveyed existing major landscape scale conservation initiatives for successes, failures and future directions and synthesized common themes. These themes included scale, importance of social and economic networks, leadership, governance, funding, conservation planning, the role of protected areas and communication. We discuss the emergence of national policy relating to National Wildlife Corridors in Australia and the relationship of this policy to the long standing commitment to build a comprehensive, adequate and representative National Reserve System. Finally we outline areas for further research for connectivity conservation projects in Australia.
\end{abstract}

KEYWORDS: connectivity, wildlife corridors, conservation networks, landscape scale conservation, Australia

\section{INTRODUCTION}

The Convention on Biological Diversity Strategic Plan for Biodiversity 2011-2020 (Aichi Targets), committed parties to the convention to establish 'ecologically representative and well connected systems of protected areas and other effective area-based conservation measures' as part of Target 11. Woodley et al. (2012, p. 29) recommend that 'countries need to move into the next phase of protected area and conservation planning by incorporating connectivity between protected areas at both regional and national scales, including transboundary conservation areas'.

Australia has seen significant advances in recent times in creating networks and initiatives that seek to restore and link up natural habitats at a landscape scale. These efforts have evolved under a range of names including 'biosphere reserves', 'wildlife corridors', 'conservation management networks', and 'biolinks' (see Box 1) and collectively seek to achieve many aspects of the emerging field of connectivity conservation, amongst other things. Such initiatives have been developed by a range of contributors including governments, private individuals, and conservation NGOs and occur at various scales from cross continental 'wildlife corridors' to regional conservation management networks.

Until now there has been relatively little analysis of these diverse and practical initiatives in a single synthesis, but a recent project has assembled the experiences of practitioners from 14 networks and corridor initiatives (Figure 1), to fill the void between the theoretical ecological proposals and research in technical journals and the practical projects that have been operating in the field (i.e. Fitzsimons et al., 2013). The facilitators/ coordinators of the connectivity initiatives were asked to document the history of the initiative, successes, constraints and directions for the future (Figure 1 highlights the initiatives surveyed as part of this research). These experiences were complemented by those of policy makers and organizations seeking to design and implement 'networks of networks' beyond the individual initiative, as well as broader perspectives from researchers in the fields of ecological science and socioeconomics (see Fitzsimons et al., 2013). This information is synthesised in this paper. Such information is important to not only inform policy makers, land 


\section{BOX 1. DIFFERENT TYPES AND NAMES OF MULTI-TENURE CONSERVATION INITIATIVES IN AUSTRALIA}

Biosphere Reserves are an international UNESCO designation and are concerned primarily with integrating biodiversity conservation with ecologically sustainable development across a variety of land tenures and uses (UNESCO; 1995; Brunckhorst et al., 1997). The theoretical biosphere reserve model revolves around a 'core' protected area managed primarily for nature conservation, a 'buffer' zone where activities that impact on the biodiversity of the core are minimised, and a 'transition' zone, where the sustainable use of natural resources is encouraged.

Biolinks are identified broad areas of the landscape at the subcontinental scale in which the functional ecological connectivity for biodiversity is enhanced and/or restored in order to provide space for species to 'self adjust' to changing environmental conditions (e.g. Mansergh et al., 2008).

Conservation Management Networks (CMNs) are biophysical networks of remnant vegetation sites across a variety of tenures and a social network of managers, owners and interested people (Thiele \& Prober, 2000). A CMN brings together the social and biophysical networks in order to improve land management and biodiversity outcomes. The term '

Wildlife Corridors' has multiple meanings in Australia. It can refer to narrow bands of native vegetation connecting core habitat areas but more recently has been adopted by the Australian Government as the label for large-scale connectivity conservation networks (i.e. National Wildlife Corridors).

See Fitzsimons et al.(2013) for greater detail on each of these models and case studies on where they have been applied in Australia.

managers, facilitators and scientists, but to stimulate even greater conservation efforts 'on the ground'.

The initiatives are being implemented across multiple land tenures (including public, private and Indigenous owned or leased land) and the aim of the project was to identify some critical common lessons that have been learnt already by practitioners in this new and evolving field. In particular, we were keen to see if there were emerging models of governance which could potentially be adapted by new entrants into connectivity conservation (nationally and internationally), so that they did not need to 'reinvent the wheel' in establishing their network.

This paper describes some of the lessons from practical, 'on the ground' implementation of landscape scale and connectivity conservation projects in Australia. We also provide an outline of the Australian Government's recently released National Wildlife Corridors Plan (DSEWPC, 2012) and suggest future research needs for the evolving field of implementing and managing largescale, multi-tenure conservation networks. Initiatives featured include those from all Australian states and territories, and many initiatives which cross state and territory boundaries.

Although there is already a significant literature on ecological connectivity and connectivity conservation both internationally (e.g. Soulé \& Terborgh, 1999; Crooks \& Sanjayan, 2006; Hilty et al., 2012) and for Australia (e.g. Saunders et al., 1996; Bennett, 2003; Soulé et al., 2004; Lindenmayer \& Fisher, 2006; Mackey et al., 2010), our focus here is on practical experiences with implementing large scale, on the ground connectivity initiatives in real landscapes.

\section{COMMON THEMES IN AUSTRALIAN CONNECTIVITY PROJECTS}

There were a number of clearly recurring themes that emerged from the analysis of operating connectivity projects in Australia. These are described under separate headings below.

\section{- $\quad$ Scale}

The scale of the operation of a network was a topic discussed by many of the project coordinators. Many of the larger corridor initiatives highlighted that they considered a large scale of operation to be important for ecological function and for creating an inspiring vision. However, operating at such a large scale was also recognized to have significant challenges, particularly for coordination, governance and communication. Almost all of the larger corridor initiatives which operated at continental or sub-continental scale therefore divided their total area into smaller 'operating units' or 'regional partnership areas'; landscape zones that reflected similarities in ecological or social attributes. The identification of groups with their regional landscape was considered to be important, as was effective and regular communication, both of which contribute to the important element of social connectedness, . 


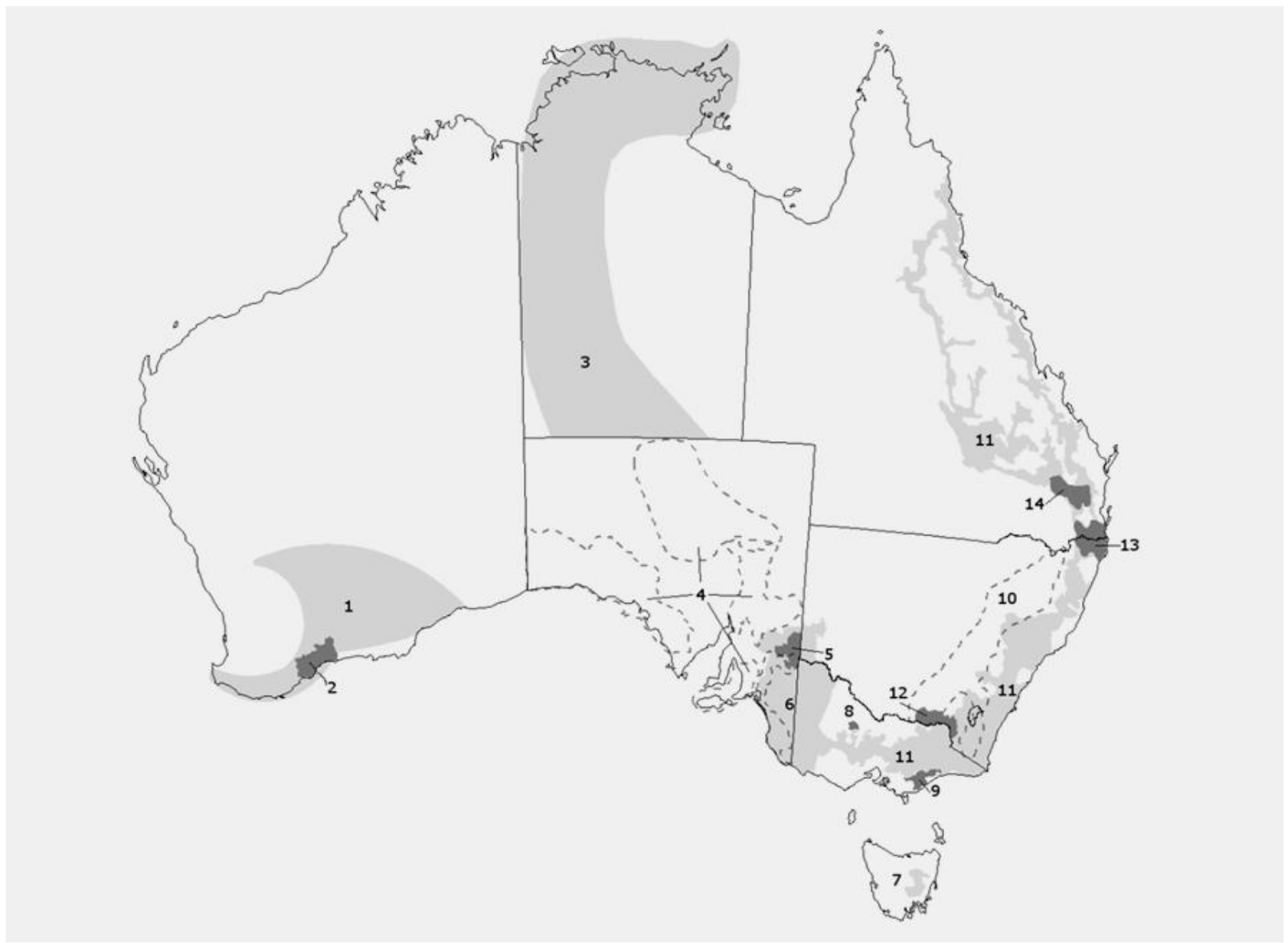

Figure 1. Australian connectivity conservation initiatives surveyed as part of this project. Differences in shading differentiates overlapping initiatives. 1 - Gondwana Link, 2 - Fitzgerald Biosphere Reserve, 3 - Territory Eco-link, 4 - South Australian NatureLinks, 5 - Riverland (Bookmark) Biosphere Reserve, 6 - Habitat 141 ${ }^{\circ}, 7$ - Tasmanian Midlandscapes, 8 - Wedderburn Conservation Management Network, 9 - Gippsland Plains Conservation Management Network, 10 - Grassy Box Woodlands Conservation Management Network, 11 - Great Eastern Ranges Initiative, 12 - Slopes to Summit, 13 - Border Ranges Alliance, 14 - Bunya Biolink. Note: 'Slopes to Summit' and 'Border Ranges' are regional landscape projects within the larger Great Eastern Ranges Initiative.

\section{- The importance of a shared and guiding vision}

Landscape-scale conservation networks, as well as the larger corridor initiatives, inspire people, help create conservation communities and provide opportunities where individuals can see their conservations efforts make a difference. Such 'stories' provide a narrative that becomes a powerful basis for engagement, governance and decision-making. A key element is a shared vision that describes a desired future landscape or biodiversity condition and seeks the involvement of people in achieving this outcome. The vision is combined with several subsidiary goals and usually supported by a plan that identifies aspirational targets and priorities for investment. While the vision is an important part of any initiatives' success, it may not be static and can evolve over time and with increased ecological community understanding and feedback, provided it brings its communities along with the evolution of the initiative.

\section{- Social and economic networks are critical elements of success}

Conservation management is required across multiple tenures in order to protect and restore biodiversity on a landscape-wide basis, and different connectivity conservation strategies are needed in different Australian landscapes. This is because the type of conservation actions required in cleared and fragmented forest and woodland landscapes can be different to the contiguous habitats for arid and northern Australia or from periurban areas. In different landscapes and communities the social willingness, and economic circumstances of landholders and communities, require quite different solutions and mixes of programmes. For example, in the more intact habitats typical of northern and central Australia the inclusion of Indigenous Protected Areas and pastoral properties, is important if not essential, whilst initiatives in fragmented forest and woodland landscapes of southern and eastern Australia (such as 


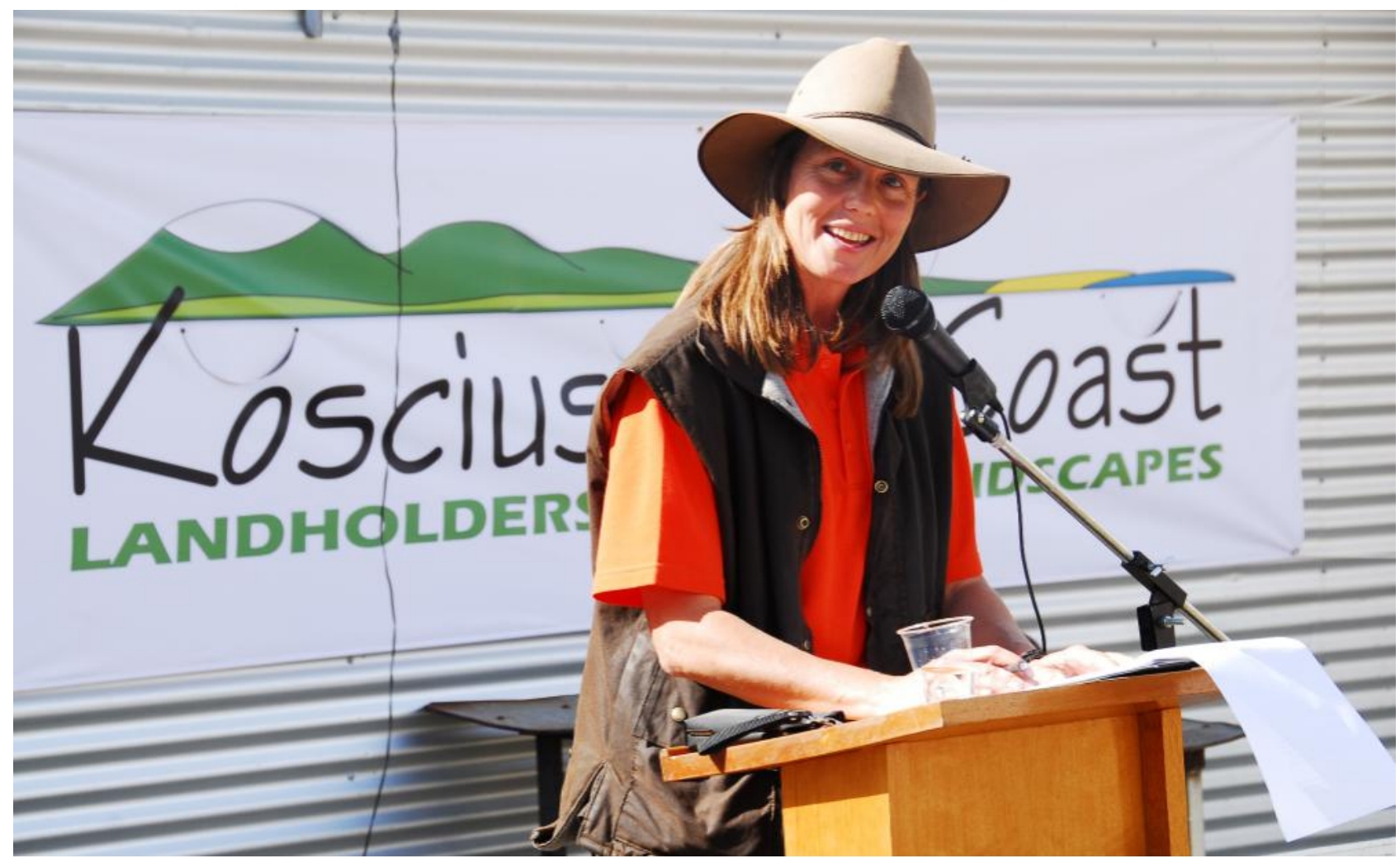

Kosciuszko2Coast partnership facilitator, Lauren Van Dyke, launching the inaugural Kosciuszko2Coast Open Day event on 13 April 2008 on a landholders property near Bredbo, New South Wales. Kosciuszko2Coast is a regional landscape projects within the larger Great Eastern Ranges Initiative 으 Ian Pulsford

Gondwana Link, the Great Eastern Ranges Initiative, Habitat $141^{\circ}$ and many Victorian conservation management networks) utilise an integrated range of voluntary conservation instruments and programmes. These include the establishment of private protected areas by NGOs and/or encouragement of landholders to sign in-perpetuity conservation agreements, and habitat restoration projects through short and long-term grant agreements with various funding bodies.

A key challenge for some initiatives is to be able to maintain partner and community interest once initial funding sources are discontinued or grant applications are unsuccessful due to changing priorities of funding bodies. There can be mismatch between partner and community expectations when a vision is not matched by sufficient funding to make an impact quickly enough, with this loss of social capital being a potential threat to the sustainability of the initiative. The strength of committed leadership over long periods was considered a key factor for success.

Programmes built on trust and openness appear to be more resilient in hard times, hence investing the time and effort early in development to build trust was highlighted by many initiatives. Another critical element is the achievement of visible and tangible on the ground results early on. Initiatives also reported on the importance of building on past conservation programmes and activities that were in operation prior to the formation of the connectivity/landscape initiative. These past activities are likely to have built important social networks and shared visions. Finally, it is critical to maintain a core group of volunteers to ensure the continuity of the programme if a facilitator, or equivalent government officer, is lost through leave, forced redundancies, 'burn-out' or loss of funding.

\section{- Leadership and the notion of 'champions'}

Leadership of initiatives was provided usually at several levels. As with so many other endeavours in nature conservation and natural resources management, many initiatives are instigated by an individual (or a few individuals) with drive, energy, passion, commitment and strong personalities who inspire others to join in. In addition, they also inspire sponsorsto provide critical funds and resources. The challenge is to have succession planning in these groups in case the leader 'burns out' and to build a leadership group that is supported by external champions. These may include influential individuals in business, government or wider community. The role of a dedicated 'facilitator' was highlighted in the various case studies as an essential element of success for connectivity initiatives. At the 
same time, the often short-term and uncertain security of funding for these positions was seen as a major limitation to the operation of these initiatives. This situation is not unique to connectivity initiatives; it is cited as a common limitation to natural resource management activities more generally in Australia (e.g. Robins \& Dovers, 2007; HC Coombs Policy Forum, 2011).

\section{- Governance}

Connectivity conservation initiatives seek to coordinate many actions, undertaken by diverse players, across multiple scales. Designing collaborative governance arrangements that harness the energies and capacities of these many players remains a challenge for conservation connectivity networks. The case studies revealed that there are a wide variety of governance models for connectivity initiatives in Australia. These ranged from top down approaches initiated by government (e.g. Great Eastern Ranges Initiative, Territory Eco-link, South Australian NatureLinks, Wedderburn Conservation Management Network) to non-government organizationinitiated networks such as Gondwana Link and Bunya Biolink, to a mix of both (e.g. Tasmanian Midlandscapes).

Large scale conservation initiatives in Australia need strong, but not necessarily complex, governance arrangements. There is currently a diverse array of systems which reflects a diverse array of reasons and motivations for establishment and the different mix of groups involved. What works in one place may not easily be transferred as a successful model elsewhere.

Governance mechanisms must also be flexible and adaptive to changes in knowledge and context, and evolution of governance arrangements has been documented for a number of networks (see also Fitzsimons \& Wescott, 2008a). The diversity of partners and the range of spatial scales of these initiatives are likely to require new modes of governance that span multiple scales and diverse interests. However, it has been possible to identify some governance principals that are common requirements for all successful initiatives.

These principals can be framed around the requirements for communication, collaboration and coordination. Within a few years there may well be enough experience and data in to draft a 'template' of successful governance and coordination arrangements so that the 'wheel is not reinvented' continuously or the same mistakes are not repeated.

\section{- $\quad$ Funding}

Funding arrangements varied between initiatives but primarily consisted of government, philanthropic and corporate funding to varying extents. Not surprisingly, a lack of funding for on the ground actions was identified as a major limitation for many initiatives.

Connectivity initiatives in Australia face a number of risks in delivering on their potential, due to the need to build investment at scale (particularly if a threshold investment is needed to achieve benefits), the organizational challenge of landscape-scale conservation, scientific and implementation uncertainties, and misalignment of goals and opportunities and even the ability to prioritise actions based on scientific and social criteria. A number of initiatives are encouraging new investment tools, such as capitalizing on the emerging carbon market, although offsets and credits are still a relatively new concepts and these funding opportunities at the scale required for landscape restoration are still in their relative infancy in Australia.

The two biosphere reserves established under the UNESCO Man and Biosphere programme that were examined (i.e. Fitzgerald and Riverland) both highlighted a 'reduction of government funds as a significantly factor in loss of momentum. As time progressed, interest by both the state and national governments waned and most of their input became inkind. During the writing of this paper the fragility of some corridor initiatives was also demonstrated with the withdrawal of funding for Territory Eco-link by the new Northern Territory Government in late 2012 (Conlan, 2012). This initiative was particularly vulnerable as its coordinating staff were funded only by the government, with little if any other funding.

The final point concerning funding is the security and nature of current government funding arrangements which typically sees funds directed for relatively short term projects whose continuity is at risk from change in government priorities. Several case studies noted the significant impact from loss of a facilitator or other staff when funds cease and the difficulty of sustaining organisations under these circumstances. As well, there is often little or no provision for operational expenses for NGOs and government agencies participating in connectivity initiatives. Most money is short-term and directed at site-specific projects. Without funding for continuing stewardship programmes and operational expenses much of the effort on initial on-ground work could be wasted. Sustainability should be a key requirement to funding. 


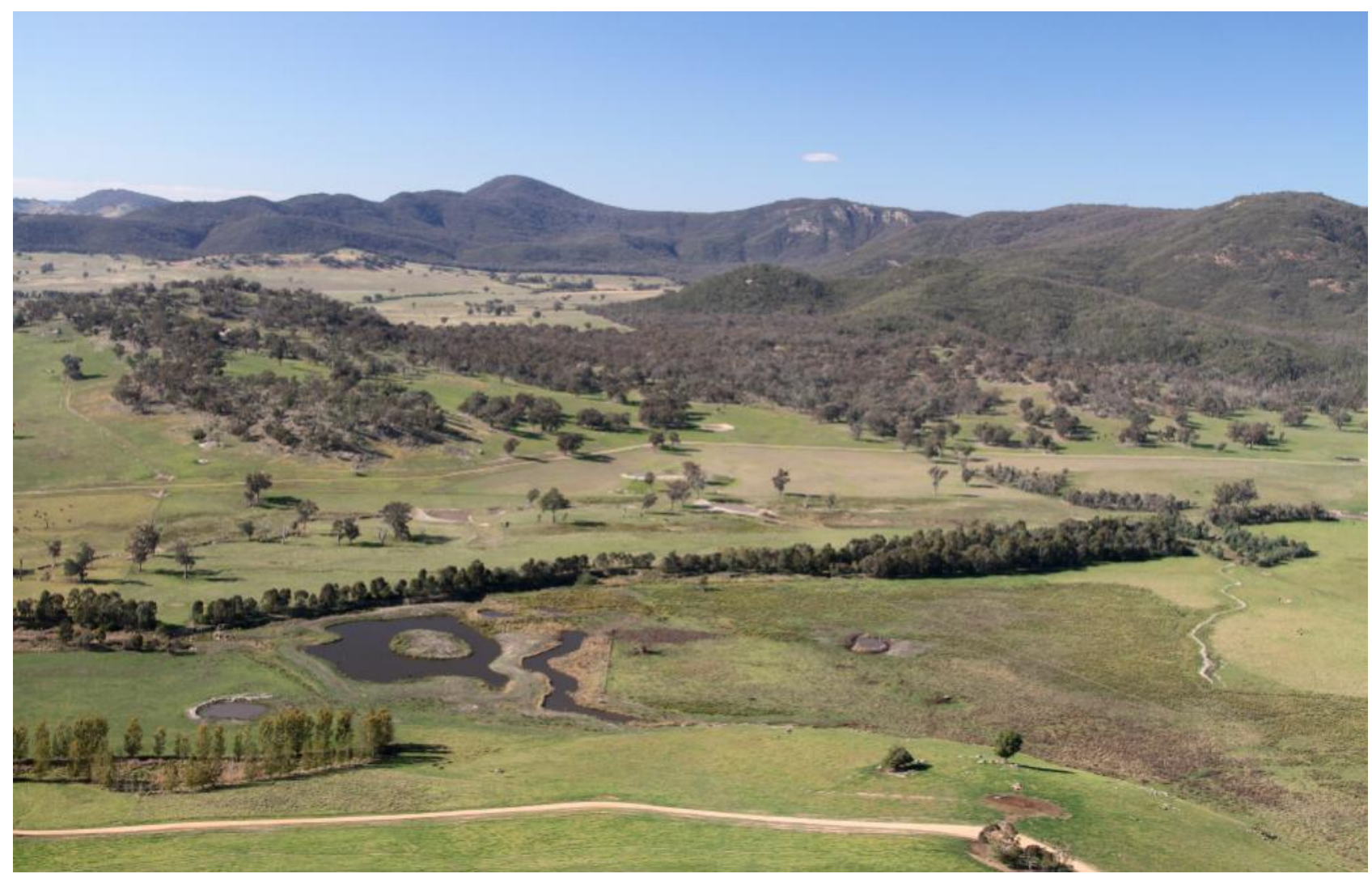

Habitat links extend from Woomargama National Park into surrounding private farm lands; part of the Slopes to Summit section of the Great Eastern Ranges Initiative, New South Wales @ Ian Pulsford

\section{- Conservation planning and delivery of broader natural resource management objectives}

The preparation of a conservation plan which contained goals and identified areas for conservation activities and investment was considered important by most initiatives. An ability to spatially prioritise conservation actions is also important for demonstrating the most efficient allocation of limited resources when reporting back to funding bodies. Methods used by the different initiatives varied considerably depending on the availability of spatial information and analytical skills. Connectivity initiatives were also considered to be useful delivery mechanisms for other natural resource management objectives, at national and state levels. For example, South Australia's NatureLinks aligned well with the principles underpinning regional natural resource management planning.

\section{- Monitoring, evaluation and reporting}

Reporting on progress is a requirement of most funding bodies and is essential for demonstrating progress to partners and to ensure that support is maintained. Effective monitoring provided the essential information required so that an adaptive approach to setting priorities for further investment can be made for achieving long-term goals. It is also essential to ensure that taxpayers and private investors are receiving value for money for these long-term investments. For many initiatives, limited and inadequate resources have been made available by funding bodies or agencies to develop monitoring, evaluation and reporting systems. Nonetheless, ecological monitoring does often occur at the individual site-scale (i.e. protected areas or private conservation lands) within connectivity initiatives and aligning these often disparate efforts and methods should be a high priority. Under the National Wildlife Corridors Plan (see below) the Australian Government has undertaken to develop guidelines and provide information on monitoring, reporting and evaluation (DSEWPC, 2012); however it remains to be seen whether adequate funds will be provided so that suitable indicators for accurately measuring progress at various spatial scales can be established.

\section{- $\quad$ Role of existing and new protected areas}

Protected areas and remnant vegetation provide the essential core components for most multi-tenure connectivity initiatives. All initiatives sought to improve the conservation and management of areas around and between these core protected areas by either focusing on protecting or better managing properties with significant 
ecological value and/or actively restoring cleared or degraded properties that provide strategic linkages.

The mechanisms used varied but included a mix of land purchase for conservation (as public or private protected areas), signing of in-perpetuity conservation covenants or shorter term management agreements linked to stewardship payments, or non-binding voluntary agreements. The mix of these options used depended on the underlying land tenure, types of investment by government and non-government sectors and social drivers. For example, in some regions, land purchase was not an option for social or legal reasons, and new, innovative approaches were developed to protect freehold or Indigenous lands. These included partnership agreements with several non-government conservation organisations such as Bush Heritage Australia, as well as government environment agencies.

\section{- Communication}

A key element of maintaining and enhancing a connectivity network was to create and maintain a communication system so that disparate members often separated by substantial distances are linked together. This usually required some dedicated resources to run a web site, prepare newsletters, videos, brochures, workshops, meetings and publications.

\section{THE AUSTRALIAN GOVERNMENT'S NATIONAL WILDLIFE CORRIDORS PLAN}

In November 2012, the Australian Government released a National Wildlife Corridors Plan (DSEWPC, 2012). This plan provides a framework for landscape scale conservation with a vision for 'diverse, connected, and healthy landscapes that support and sustain biodiversity, communities and wellbeing'. It aims to retain and restore ecological connections and emphasizes a 'new, collaborative, whole of landscape approach to biodiversity conservation...' It states that the role of the Australian Government is to 'enable and coordinate the efforts of all participants' (DSEWPC, 2012, p. 1).

The plan is in two parts, the first describing the guiding principles, objectives and foundations of the corridors Plan and the second how the government will aid the establishment of a national network of wildlife corridors. The plan outlines six corridor initiatives (p. 29) that are 'considered important foundation stones for the network of wildlife corridors': Gondwana Link, the Great Eastern Ranges Initiative, Habitat $141^{\circ}$, NatureLinks, TransAustralia Eco-Link and Tasmanian Midlandscapes. The plan provides for the establishment of a National Wildlife

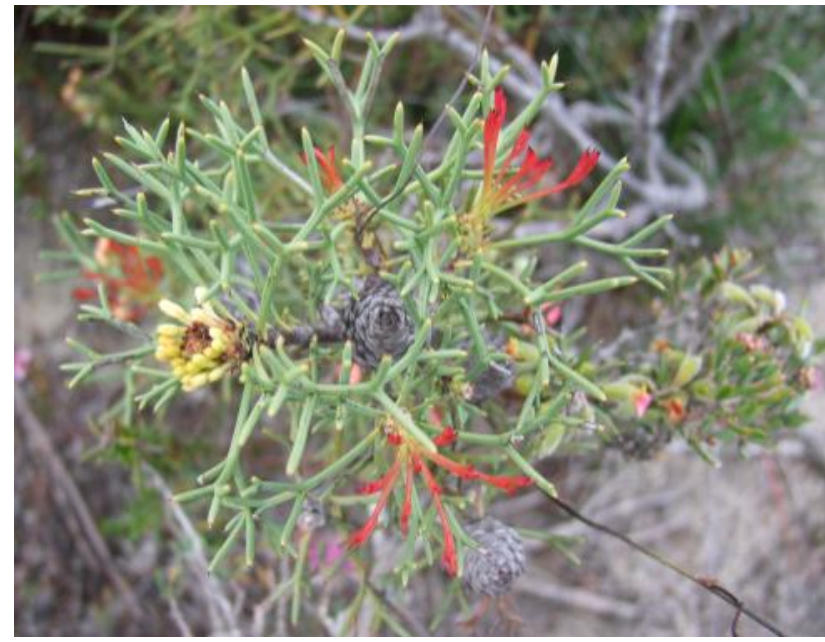

Revegetation of woodlands and heathlands in the landscape between Fitzgerald River and Stirling Range National Parks, part of Gondwana Link and a global biodiversity hotspot (C) James Fitzsimons

Corridors Council, and a process for nominating existing and new partnerships for inclusion on a National Wildlife Corridors list by the Federal Minister for Environment. They will need to meet a list of scientific and social criteria to be developed by the Council. Listing will assist the government to prioritise funding from a range of existing environmental funding programmes.

The plan suggests that the following features are common in successful projects - accountability, transparency, integrity, efficiency, flexibility, leadership, engagement and social cohesion - although it does not specify the criteria for success. The plan notably did not have any funding for implementation attached to its publication. Nonetheless the geographic regions in which the 'foundation stone' corridors occur have been recently prioritized for financial investment under the Australian Government's 'Caring for our Country' programme and the 'Biodiversity Fund' (Australian Government, 2012). Future Australian Government funding of initiatives that have been listed as National Wildlife Corridors may lead to state governments considering the benefits and commitments to multi-tenure approaches more carefully, especially where strong community support is demonstrated.

However, the push towards a much needed national policy on wildlife corridors may have had an unintended negative consequence for protected area establishment and conservation in Australia. Although the National Wildlife Corridors Plan states that the National Reserve System, Australia's network of public, private and Indigenous protected areas, to be a 'foundation stone' of the future network of National Wildlife Corridors, shortly after its release the Australian Government announced it 


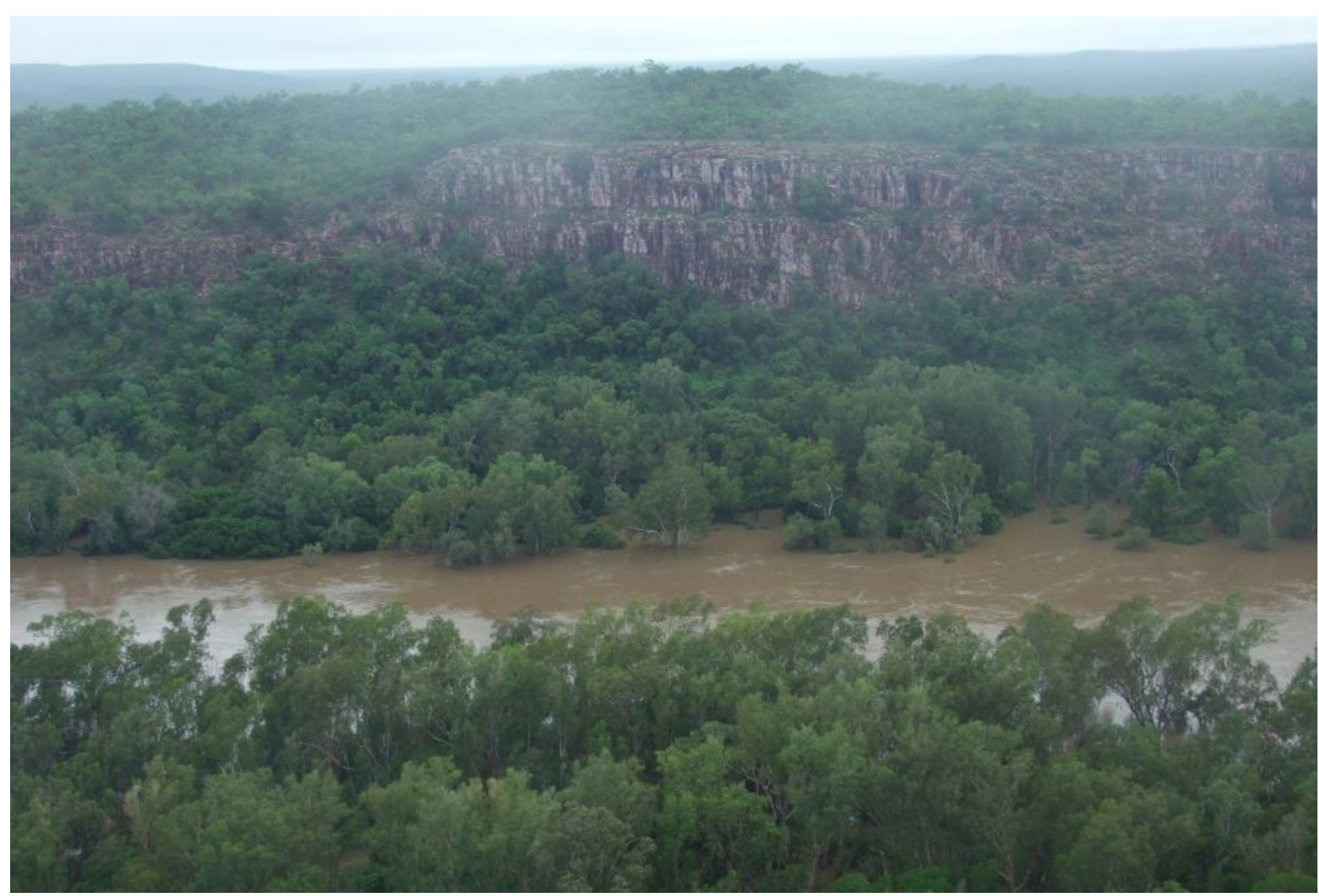

Fish River Station, a 180,000 ha property in northern Australia purchased for conservation and a key property in the 'Territory Eco-link' () James Fitzsimons

was ending nearly two decades of dedicated financial support to expand the National Reserve System (Australian Government, 2012). As funding for acquisition of high priority properties was either a key stimulus for the creation of new connectivity initiatives or an important mechanism used to advance the goals of existing initiatives, this decision may slow the advancement of the corridors concept. Perhaps more significantly it will almost certainly slow the progress towards achieving a comprehensive, adequate and representative network of terrestrial protected areas in Australia.

\section{DIRECTIONS FOR FURTHER RESEARCH}

As research into multi-tenure connectivity initiatives is still in its infancy in Australia (and internationally), there remains many areas in need of further research. Further investigation of three areas in particular would complement the work undertaken in this project and elsewhere (e.g. Fitzsimons \& Wescott, 2007, 2008 a,b,c; Worboys and Pulsford 2011; Wyborn, 2011; Fitzsimons et al., 2013), increase our understanding of networks and connectivity initiatives, and would ultimately lead to an increase in the effectiveness of multi-tenure conservation efforts.

\section{Increased research into social dynamics of networks}

Further work is needed to understand the social, political and economic dynamics of landscapes and communities. Improved knowledge of the social and demographic characteristics of those landowners participating in connectivity conservation initiatives and those that are not could provide important information and allow approaches to be tailored to attract landowners in the future and to enhance the long-term sustainability of connectivity groups and projects.

\section{Longer term changes in network characteristics}

Long-term research and analysis of ecological, social, governance and land use attributes would enhance our understanding of the forces that shape multi-tenure conservation initiatives. Of particular interest is the identification of reasons for their persistence or failure. The impact that the failure of an established network may have on landowners involved is of particular interest because disenfranchisement may lead to negative outcomes for biodiversity conservation. Longer-term research would also enable a more thorough evaluation of the contribution of networks to biodiversity 
conservation, the ultimate reason for establishing such initiatives.

\section{Comparison with other networks in Australia and internationally}

Multi-tenure connectively initiatives are proliferating in Australia, being established at a range of scales and with increased interest by government. Further comparisons between the types of initiatives and the scales they operate at, both in Australia and with international initiatives (e.g. greenline parks, transboundary protected areas, large-scale wildlife corridors), will also provide greater insight into the characteristics of multi-tenure connectivity networks and their role in protecting biodiversity. Ultimately, this will assist in identifying more effective and efficient models for biodiversity conservation across the landscape.

\section{CONCLUSION}

Australia is at a developmental phase in experimenting with a range of different approaches to achieving connectivity and landscape-scale conservation, at a range of scales from local, ecosystem-based networks to massive continent crossing linkages. This is an exciting time for conservation tempered by the need to ensure that these initiatives complement - not replace - efforts to halt vegetation loss, establish a comprehensive, adequate and representative reserve system, and address the continuing threat of climate change. Local communities, NGOs and some state governments have led the recent drive for real, on the ground connectivity conservation initiatives. The Australian Government has followed with the National Wildlife Corridors Plan that will provide a guiding national framework which in turn may increase funding and agency support for initiatives from the Australian Government. But such a plan will need bi-partisan long-term (decades not years) political support, and support from state and local governments, if it is to meet its lofty ambitions.

Whilst such national-scale plans (sometimes referred to as 'natural infrastructure building') are vital, it is important to note that most of the on the ground initiatives in Australia have developed and evolved in the absence of a national policy framework or direct Australian Government support. Considering the current strong interest in establishing connectivity initiatives, this will continue to pose challenges in balancing demand for support from initiatives in areas which may not be a high priority for conservation at a national level with encouraging the establishment of initiatives in high priority regions but where there is little local interest.
There is an urgent need to support and strengthen governance capacity of initiatives to continue to achieve more efficient and effective conservation outcomes. There is also a need to break down the silos that currently exist between supposed different approaches to connectivity and landscape-scale conservation (e.g. biosphere reserves, wildlife corridors, conservation management networks) and instead take a more holistic view of these multi-tenure conservation initiatives in policy, planning, research and communication.

Whilst governmental support for a framework of corridors is crucial, other sources of funding (from corporate to philanthropic) will be important to provide the continuity and scale of resources required to operationalize these grand visions. Given the likely increase in investment in these initiatives, providing security for the conservation outcomes achieved from that investment (e.g. through conservation covenants and other binding agreements) will be an increasing focus. This is particularly so considering the evolving, and at times fragile, nature of the initiatives. Finally this increase in investment in connectivity conservation initiatives needs to be underpinned by strong monitoring and research frameworks which ensures that best practice is identified (and rewarded) and by an effective communication network which ensures that these findings are dispersed across all projects in the country.

\section{ACKNOWLEDGEMENTS}

We thank the contributors to the Linking Australia's Landscapes project (Fitzsimons et al., 2013) for their insights and considered contribution to this project, specifically Matt Appleby, Lynn Baker, Georgia Beyer, Keith Bradby, Andrew Bridges, Andrew Cameron, Ben Carr, Stuart Cowell, Rosemary Crane, Jim Crosthwaite, Christine Cumming, Erik Doerr, Veronica Doerr, Rob Dunn, Sarah Eccles, Nick Edgar, Robyn Edwards, Simon Ferrier, Trish Fox, David Freudenberger, Jody Gates, Jane Greacen, Lainie Grigg, Gary Howling, Stella Kondylas, Judy Lambert, Harvey Locke, Duncan Mackenzie, Brendan Mackey, Ian Mansergh, Toni McLeish, Peter Morison, Wendy Murphy, Sam Niedra, Lorraine Oliver, Hannah Parris, Hugh Possingham, Ralf Regeer, Rainer Rehwinkel, Angela Sanders, Peter Spooner, Daniel Sprod, Julia Stanley, David Walker, Philippa Walsh, Stuart Whitten, Graeme Worboys, Carina Wyborn and Charlie Zammit. Glenn Johnstone kindly prepared figure 1 We also thank two anonymous referees for helpful comments on a draft of this manuscript. 


\section{REFERENCES}

Australian Government (2012). One Land-Many Stories: Prospectus of Investment 2013-2014. Canberra: Department of Sustainability, Environment, Water, Population and Communities.

Bennett, A. (2003). Linkages in the Landscape: The Role of Corridors and Connectivity in Wildlife Conservation. Gland, Switzerland and Cambridge, UK: IUCN.

Brunckhorst, D.J., Bridgewater, P. and Parker, P. (1997). The UNESCO Biosphere Reserve Program comes of age: learning by doing; landscape models for sustainable conservation and resource use. In P. Hale and D. Lamb (Eds) Conservation Outside Nature Reserves. (Eds). Brisbane: Centre for Conservation Biology, University of Queensland. P 176-182.

Conlan, M. (2012). Parks and Wildlife to receive funding increase. Minister for Parks and Wildlife Media Release, 4 December 2012. Available: http://newsroom.nt.gov.au/ index.cfm ? fuseaction $=$ view Release $\& i d=10126 \& d=5$ [Accessed 7 December 2012]

Crooks, K.R. and Sanjayan, M. (eds) (2006). Connectivity Conservation. Cambridge, UK: Cambridge University Press.

DSEWPC (2012). National Wildlife Corridors Plan: A framework for landscape-scale conservation. Canberra, Australia: Department of Sustainability, Environment, Water, Population and Communities.

Fitzsimons, J., Pulsford, I. and Wescott, G. (eds) (2013). Linking Australia's Landscapes: Lessons and Opportunities from Large-scale Conservation Networks. Melbourne, Australia: CSIRO Publishing.

Fitzsimons, J.A. and Wescott, G. (2005). History and attributes of selected Australian multi-tenure reserve networks. Australian Geographer 36: 75-93.

Fitzsimons, J.A. and Wescott, G. (2007). Perceptions and attitudes of land managers in multi-tenure reserve networks and the implications for conservation. Journal of Environmental Management 84: 38-48.

Fitzsimons, J.A. and Wescott, G. (2008a). Evolving governance arrangements in multi-tenure reserve networks. Environmental Conservation 35: 5-7.

Fitzsimons, J.A. and Wescott, G. (2008b). The role of multitenure reserve networks in improving reserve design and connectivity. Landscape and Urban Planning 85: 163-173.

Fitzsimons, J.A. and Wescott, G. (2008c). Ecosystem conservation in multi-tenure reserve networks: The contribution of land outside of publicly protected areas. Pacific Conservation Biology 14: 250-262.

HC Coombs Policy Forum (2011). Natural Resource Management Policy and Planning in Australia. Synthesis of broad issues and opportunities: Document I, HC Coombs Policy Forum-Fenner School of Environment and Society NRM initiative. Canberra, Australia: Australian National University.

Hilty, J.A., Chester, C. and Cross, M. (2012). Climate and Conservation: Landscape and Seascape Science Planning and Action. Washington, D.C. USA: Island Press.

Lindenmayer, D.B. and Fisher, J. (2006). Habitat Fragmentation and Landscape Change: An Ecological and Conservation Synthesis. Collingwood, Australia: CSIRO Publishing.

Mackey, B., Watson, J. and Worboys, G.L. (2010). Connectivity Conservation and the Great Eastern Ranges Corridor. Sydney, Australia: ANU Enterprises Pty Ltd.
Mansergh, I., Cheal, D. and Fitzsimons, J.A. (2008). Future landscapes in south-eastern Australia: the role of protected areas and biolinks in adaptation to climate change. Biodiversity 9 (3-4): 59-70.

Robins, L. and Dovers, S. (2007). Community-based NRM boards of management: are they up to the task? Australasian Journal of Environmental Management 14: 111-122.

Saunders, D.A., Craig, J.L. and Mattiske, E.M. (eds) (1996). Nature Conservation 4: The Role of Networks. Chipping Norton: Surrey Beatty and Sons.

Soulé, M.E., Mackey, B.G., Recher, H.F., Williams, J., Woinarski, J., Driscoll, D. and Dennison, W.C. (2004). The role of connectivity in Australian conservation. Pacific Conservation Biology 10: 266-279.

Soulé, M.E. and Terborgh, J. Eds (1999). Continental Conservation: Scientific Foundations of Regional Reserve Networks. Washington D.C. USA: Island Press.

Thiele, K. and Prober, S. (2000). Conservation Management Networks-a model for coordinated protection and management of remnant vegetation. In: Balancing Conservation and Production in Grassy Landscapes, Proceedings of the Bushcare Grassy Landscapes Conference, Clare, South Australia 19-21 August 1999. (Eds T. Barlow and R. Thornburn) pp. 58-63. Canberra: Environment Australia.

UNESCO (1995). Biosphere Reserves: The Seville Strategy and the Statutory Framework for the World Network. Paris, France: UNESCO.

Woodley, S., Bertzky, B., Crawhall, N., Dudley, N., Londoño, J.M., MacKinnon, K., Redford, K. and Sandwith, T. (2012). Meeting Aichi Target 11: What does success look like for protected area systems? PARKS 18 (1): 23-36.

Worboys, G.L., Francis, W. and Lockwood, M. (eds) (2010). Connectivity Conservation Management: A Global Guide. London: Earthscan.

Worboys, G.L. and Pulsford, I. (2011). Connectivity conservation in Australian landscapes. Report prepared for the Australian Government Department of Sustainability, Environment, Water, Population and Communities on behalf of the State of the Environment 2011 Committee, Sustainability, Environment, Water, Population and Communities, Canberra.

Wyborn, C. (2011). Landscape scale ecological connectivity: Australian survey and rehearsals. Pacific Conservation Biology 17: 121-131.

\section{ABOUT THE AUTHORS}

James Fitzsimons is the Director of Conservation for The Nature Conservancy's Australia Programme and an Adjunct Associate Professor at the School of Life and Environmental Sciences, Deakin University. His particular research interests are in the fields of protected area policy, practical conservation planning and mechanisms to integrate conservation outcomes on public and private lands. He has worked in the fields of conservation policy and planning for government environment departments and agencies, and for nongovernment environment organisations. His $\mathrm{PhD}$ research focused on multi-tenure conservation networks and has been involved with Conservation Management 
Network policy in Victoria and securing large-scale conservation outcomes in the Gondwana Link and Territory Eco-link initiatives.

Ian Pulsford is a specialist in protected areas and linking landscapes, with over thirty two years experience in leadership, senior management, conservation assessment, policy and practice. He was a divisional manager with the NSW Department of Environment and Climate Change and then the founding manager of the Great Eastern Ranges Initiative from 2007 to 2010. He is a member of the IUCN WCPA and has served on various government committees, including as an independent expert on a panel advising the Australian Government on the preparation of the National Wildlife Corridors Plan.

Geoff Wescott is Associate Professor of Environment at Deakin University's Melbourne Campus. He is a former Chair of the Victorian National Parks Advisory Council, Deputy Chair of Parks Victoria and Chair of the Marine and Coastal Community Network. He is currently Vice President of the Australian Coastal Society and a member of Zoos Victoria's Board of Directors. He is also a member of the Wedderburn Conservation Management Network in Victoria.

\section{RESUMEN}

Australia ha experimentado un rápido crecimiento en la creación de redes de tierras gestionadas para la conservación de la conectividad, a escala de paisaje y subcontinental. Estas redes se denominan de diversas maneras, incluyendo reservas de biosfera, corredores biológicos (biolinks), corredores de vida silvestre y redes para la gestión de la conservación. Su establecimiento ha variado desde iniciativas gubernamentales hasta iniciativas promovidas por organizaciones no gubernamentales y propietarios de tierras. Examinamos las iniciativas de conservación existentes a nivel de paisaje para determinar éxitos, fracasos y orientaciones futuras y sintetizamos temas comunes. Estos temas incluyeron escala, importancia de las redes sociales y económicas, liderazgo, gobernanza, financiación, planificación de la conservación, función de las áreas protegidas y comunicación. Examinamos el surgimiento de la política nacional relacionada con los corredores de vida silvestre en Australia y su relación con el compromiso a largo plazo para construir un sistema de parques nacionales integral, adecuado y representativo. Y por último, destacamos áreas para futuras investigaciones para proyectos de conservación de la conectividad en Australia.

\section{RÉSUMÉ}

L'Australie a connu une croissance rapide du nombre de réseaux de terres gérées dans l'optique d'une conservation de la connectivité, quels que soient les types de régimes fonciers et l'échelle (par exemple à l'échelle du paysage ou sous-continentale). Ces réseaux peuvent prendre la forme de réserves de biosphère, de bioliens, de couloirs de la vie sauvage et de réseaux de gestion de la conservation. Leur création peut être le fait d'initiatives de l'État ou d'organisations non gouvernementales et de propriétaires intéressés. Nous avons évalué les principales initiatives en faveur de la conservation à l'échelle du paysage, leurs succès, leurs échecs et leurs orientations futures, et avons rassemblé les thèmes communs. Ces thèmes incluent notamment l'échelle, l’importance des réseaux économiques et sociaux, le leadership, la gouvernance, le financement, la planification de la conservation, le rôle des aires protégées et la communication. Nous avons également étudié l'émergence d'une politique nationale relative aux couloirs nationaux de la vie sauvage en Australie, et la relation entre cette politique et l'engagement à long terme portant sur la construction d'un système national de réserves significatif, adéquat et représentatif. Enfin, nous avons souligné les domaines méritant d'être approfondis pour des projets de conservation de la connectivité en Australie. 